International Business Management 13 (1): 1-13, 2019

ISSN: 1993-5250

(C) Medwell Journals, 2019

\title{
Corporate Social Responsibility Study on Companies Listed at the Saudi Stock Exchange
}

\author{
Ohoud Mohammed Al-Otaibi \\ Department of Philosophy, Faculty of Economics, University of Cairo, Giza, Egypt
}

\begin{abstract}
This study examined the application of corporate social responsibility by the Saudi companies listed at the stock market. Also, the study aimed to construct a composite index for social responsibility. A descriptive research design was adopted. Corporate Social Responsibility was measured using CSR index which including six activities. Company performance was measured using net income, return on assets and return on equity. Descriptive statistics, t-test, ANOVA regression and correlation analysis were carried out. Descriptive statistics were done to describe the data set of Saudi companies which represents 15 sectors for the year 2015. Findings showed high level of CSR application among Saudi companies listed at stock markets and the performance of CSR towards customers was the highest when compared to the other activities. Significant differences were found between companies regarding CSR performance. The study, however, found no significant relationship between CSR and size and having an independent department for CSR does not affect the application of social responsibility activities. The study recommended that for improving CSR governance in particular, Saudi companies must formalizing governance policies: codes and guidelines and ensuring the sustainability of the business.
\end{abstract}

Key words: Social responsibility activities or scales, financial performance, CSR, Saudi companies, ANOVA, performance

\section{INTRODUCTION}

Corporate social responsibility has long been absent from our reality and it soon emerged after the world realized its importance and that it was not isolated from society. Therefore, responsibility has become one of the principles that society aspires to implement in order to face many social problems, the most important of which are the increase in poverty and unemployment, especially, with the reduction of the role of governments in economic and social development and the shift towards privatization and abandoning many of their social roles and the transition of these roles to business organizations (DeGeorge, 1995).

Companies in Saudi Arabia have become interested in social responsibility and develop and research within their activities in order to contribute to development. Corporate social responsibility patterns and programs have been successfully achieved in many areas including health and education and have helped create jobs that have contributed significantly to reducing unemployment among low-income families, poor families, orphans and people with special needs. A social responsibility council has been established to support the social responsibility activities and projects adopted by enterprises to develop society and meet its needs. It seeks to mobilize support for sustainable development programs in the Riyadh Region in particular and in the Kingdom in general.

The current study aims at finding out whether Saudi companies play their role in social responsibility. The researcher also seeks to know the extent to which CSR is applied by assessing the different aspects of CSR. The study also attempts to build a composite index of social responsibility to evaluate the companies and arrange them accordingly.

In the next section of this study the problem statement of the study, its importance, objectives, research questions, hypothesis and limitations will be reviewed in addition to the theoretical and conceptual framework of the study and methodology and then the results and method of building the CSR index will be presented.

Statement of the problem: The problem of the study focuses on the following main question: do Saudi companies play their role in social responsibility.

Significance of the study: The importance of the current study is that it will identify the performance of corporate social responsibility in the Kingdom of Saudi Arabia 
(KSA) and determine the impact of the company size on its performance of social responsibility activities. The study will build an index specially designed to evaluate the companies in the Saudi Stock Market. This is the first step followed by the ranking of these companies according to its CSR The importance of this index is that it has not been applied in Saudi Arabia to the present time, despite the efforts of the Saudi Capital Market Authority which tried to build an index but not yet, completed. The results of this study can also help in the financial decision-making process and help to formulate appropriate strategies for the application of social responsibility.

\section{Aims, questions and hypothesis}

Research objectives:

- To determine the extent to which CSR is applied by evaluating its different aspects

- To build a composite index of social responsibility to evaluate and ranking the companies accordingly

Research questions: The problem of this study focuses on the following main question: are Saudi companies play its role in social responsibility? and the following sub-questions arise from this question.

To what extent Saudi companies applying CSR Standards in general? Are there significant differences at level (0.05) in the degree of application of social responsibility standards by Saudi companies according to selected independent variables such as (sector, availability of a separate section for social responsibility in the company, years of listing in the Saudi Stock Market and company capital? Is there a difference between companies in regard to social responsibility performance? Does the size of the company affect its social performance? Is there a statistically significant relationship at level (0.05) between the social responsibility performance and size of the company?

\section{Research hypothesis}

The main hypothesis: Saudi companies do not play their role in social responsibility.

Second hypothesis: There are significant differences at level (0.05) in the degree of application of social responsibility standards by Saudi companies according to selected independent variables such as (sector, availability of a separate section for social responsibility in the company, years of listing in the Saudi Stock Market and company capital.

Third hypothesis: There is no difference between companies in regard to social responsibility performance.
Fourth hypothesis: Company size have no affect on social performance.

Fifth hypothesis: There is a statistically significant relationship at level $(0.05)$ between the social responsibility performance and size of the company.

Scope of the study: The overarching aim of the research was to examine the current status of CSR in companies listed at the Saudi Stock Exchange. This study was conducted in Riyadh, Kingdom of Saudi Arabia during the year 2016. Samples were taken from companies listed at the Saudi Stock Exchange which include all employees and those who have knowledge of social responsibility programs in the company.

The objective limits: The study was limited to the subject of social responsibility and its various dimensions and to what extent the companies apply CSR programs and their impact on the financial performance of the companies.

Institutional limits: The field study focused was on companies listed at the Saudi Stock Exchange, through a survey prepared by the researcher to identify the reality of social responsibility. Research on the financial performance of companies and financial data extracted from financial reports published in the period 2011-2015. The General Authority for Statistics, National Accounts Indicators, 2016 Annual Report of the Financial Markets (Tadawul) 2015.

\section{Literature review}

Theoretical and conceptual framework: In 1950's of this century the major focus was on companie's responsibilities towards the society and performance of charitable works. In 1960 's major events, peoples and ideas have contributed in description of social changes that emerged in this decade. However, in 1970's the business managers had applied functions of traditional works when dealing with issues of social responsibilities of the companies meanwhile commercial business and social benefits were nearly fulfilled in I980's and the companies became more responsive to the stakeholders.

During 1990's, the idea of social responsibility of the companies was almost accredited on global level as well as it has been associated with strategic literature and lately in 2000's, the social responsibility of the companies became an important strategic issue (Moura-Leite and Padgett, 2011). The conception of the social responsibility of institutions has witnessed substantial changes over time and is still develops in accordance to the progress and development of the society as there are many 
conceptions but there is no unified conception to social responsibility. Below here some of these conceptions. The world business council for sustainable development has defined the social responsibility as "continuing commitment of business institutions to behave ethically and contributing in achieving economic development and strive to improve living conditions of manpower and their families in addition to the local community and the society as a whole".

The international bank has defined social responsibility as "a commitment with contribution in sustainable development by working with employees of social responsibility, local community and the society as whole to improve the standard of living of peoples by a method that serve the trade and the development in simultaneous way".

Nevertheless, we can define social responsibility of the companies in terms of what companies do and offer to the society to extent the society expects from these companies on condition that however such social responsibility shall include observance of human rights, values and ethics of the society, compliance with laws, anti-corruption, transparency and disclosure in addition of contributing in achieving sustainable development.

Regarding social responsibility, economists are divided between pro and opponents to it as each group has their arguments. The pro social responsibility group see that companies are no longer depend in terms of building their reputation on their financial position only and their evaluation is no longer depends on their profits because they became partners in the development. They depend on their argument on the following.

Companies are integral part of the society that they exist in, therefore, they should play major role in achieving the goals of that society. Profits increase on the long term as a result of social responsibility roles adopted by these companies. Social role is a reaction to criticism towards the organization in terms of its interests in profits and negligence of social requirements. The opponents see that social responsibility is contradicted with the main objective of the organization in terms of realizing profits in addition to the following.

Commitment with social responsibility tasks transforms the organization into an entity that does not differ from other government organizations. If the organization spent monies to execute social responsibility programs that means it burdens extra costs that will be reflected in increase of the price of their goods or services and therefore, an adverse impact on its position and competitive strength in the market. Regardless to pro and opponent arguments, social responsibility programs implementation remains associated mainly with culture and conviction of companies themselves and extent of impact of social responsibility on their position.

Saudi social responsibility: Kingdom of Saudi Arabia is considered like other emerging markets, especially, that related to the concept of social responsibility which started of charity nature then its developed due to the consideration given by Kingdom of Saudi Arabia to the community and environmental issues and the claims of the communities that companies must take their role in responsibilities towards the communities and environment. Therefore, some companies have adopted programs of social responsibilities which in return contribute in developing this concept but not in the same as in the advanced countries.

As we mentioned above and due to the consideration of the Kingdom given to the issues of communities and environment and the claims from Saudi community that companies should contribute and take their role towards the community which induced some companies like National Commercial Bank, Al-Rajhi Banking services and Savola Group to adopt social responsibility programs and to encourage their staff to participate in such projects. To enforce the concept of social responsibility the Kingdom have conducted some procedures from which are.

Sponsorship of some events by some government authorities of which is: the first forum of social responsibility in 2006. Launching of responsibility competitiveness Index by general authority for investment in collaboration with King Khalid Foundation and International Research Center which aim o enhance companies to adopt an effective role in social responsibility for structuring of community abilities and enhancing national competiveness but it's already ceased.

Encouraging the partnership between general and private sectors in order to propagate social responsibility culture which has extended due to decline of the role of the state in social and economic development and hence, played their role in social responsibility as follows: establishment of social canters, health services for citizens, educational services, contribution in infra structure and general facilities, supporting of governmental activities serving the community, e.g., some conferences and forums aiming to encourage investment.

Further the civil community has its contribution, one of which is the chamber of commerce and industry and considered as one of the most important entities participating in social development and organizing 
the contribution of the business sector to take this role, the chamber of commerce and industry has established a department for community service which contribute in activating the social responsibility and propagating its culture in order to achieve the sustained development.

The chamber has adopted the prize of social responsibility in order to encourage and enhance the business sector in voluntary activities to serve the community either at individual or corporation level and then established the council of social responsibility and the prize name is "Social Responsibility Prize". The nominee's for the prize is chosen from all participants of the Chamber of Commerce and Industry in Riyadh and Charities in Riyadh Region.

Nevertheless the consideration paid for this issue locally and internationally and by all concerned bodies in the Kingdom which contribute in promoting this issue there is no measurement for the performance of social responsibility for companies according to certain index including all international and local standards.

Therefore, here comes the importance of this study looking forward to shed the light for the role of social responsibility through establishing an index and in return arranging the companies according to their role in social responsibility and according to the index which is considered to establish basis for standards by which the activities of the companies will be controlled and enhance their performance for the best in supporting the Saudi community.

\section{MATERIALS AND METHODS}

For achieving the aim and objectives, the study was based on the descriptive method in order to identify the social responsibility of the companies listed on the Saudi Stock Exchange.

Study population: The study population consists of all the 175 companies listed in the Saudi Stock Exchange in the years 2015 which include 15 sectors.

Study sample: The questionnaire was distributed to all the mentioned companies which published their financial reports duly during the period (2011-2015) only 156 valid questionnaires for statistical analysis were filled. Therefore, the study was applied to a sample of (156) with response rate of $(89 \%)$ (Table 1$)$.

\section{Data collection tool}

Social responsibility activities: In order to achieve the objectives of the study and answering its questions and
Table 1: Distribution of companies by sector

\begin{tabular}{lrc}
\hline Sectors & No. & Percentage \\
\hline Insurance & 24 & 15.4 \\
Tourism and hotels & 4 & 2.6 \\
Service facilities & 2 & 1.3 \\
Publishing and media & 3 & 1.9 \\
Banks & 9 & 5.8 \\
Telecommunications & 4 & 2.6 \\
Building and construction & 14 & 9 \\
Petrochemicals & 14 & 9 \\
Retail & 17 & 10.9 \\
Transportation & 5 & 3.2 \\
Cement & 14 & 9 \\
Real estate development & 9 & 5.8 \\
Multi-investment & 7 & 4.5 \\
Agriculture and food industries & 15 & 9.6 \\
Industrial investment & 15 & 9.6 \\
Total & 156 & 100 \\
\hline
\end{tabular}

testing its hypothesis that related to the extent to which companies apply social responsibility through its various aspects and to identify the relationship between the size of the company and its social responsibility performance and to measure the social responsibility activities of the companies listed on the Saudi Stock Exchange in 2015 an administered questionnaire specifically prepared for this purpose was utilized in addition to reviewing the financial statements and financial reports of the studied companies during the period 2012-2015. The scale of CSR activities consists of 50 items arranged into 6 sub-scales as follows.

Social responsibility of the company towards the community (14) statements, social responsibility of the company towards the environment (5) statements, social responsibility of the company towards the employees (17) statements, social responsibility of the company towards customers (4) statements, corporate social responsibility and governance principles (6) statements and social responsibility and the performance of the organization (4) paragraphs in addition to the personal information of the study sample and information about the company and the financial performance of the company from 2012-2015 represented by three variables: net income return on average assets and return on the average equity.

The researcher was adopted the closed questionnaire for the subscales of CSR which identifies the possible responses to each question. The 5 points Likert scale was used where each statement of the subscale corresponds to a list of the following options (absolutely agree, agree, neutral, disagree and absolutely disagree). This scale was chosen by the researcher because it gives the respondent the chance to determine his or her positive or negative attitude towards each statement where each statement is given score according to the five points Likert scale.

Face validity was assessed by subjective evaluation of the measurement procedures which made by experts and number of academic arbitrators in order to express 
their opinion on the clarity of the statements of the questionnaire in addition to some general observations on the questionnaire in what is being assessed. The best way to use the face validity as Allen and Yen (2002) points out is to present the scale statements to a group of arbitrators to judge their validity in measuring the property to be measured.

Reliability: Measured by calculating the coefficient of Cronbach's alpha $(\alpha)$ which gave acceptable to good estimate for the CSR subscales, the coefficients values ranged between $(0.51$ and 0.973$)$. In practice, the value of alpha ( 0.60 or higher) was acceptable in human and administrative sciences (Sekaran, 2003).

Data analysis: A number of statistical methods were used to analyze the collected data in order to achieve the objectives of the study by using the Statistical Packages for Social Sciences (IBM SPSS Statistics V. 20). (Cronbach's alpha for reliability, weighted mean, standard deviation, independent samples t-test, ANOVA and regression analysis (Anonymous, 1997).

\section{RESULTS AND DISCUSSION}

Based on the analysis of the field study data, the study reached the following results:

Sample characteristics: The characteristics of the sample of the current study were that the majority of them were university graduates (68.6\%). Most of them were aged $30-40$ years with percentage of $57.7 \%$ and slightly $<$ half of the sample $(45.5 \%)$ was under the job title (employee). The study showed that $67.9 \%$ of the employees have a direct relationship to social responsibility which means that they are familiar with the terms of social responsibility and clarity in terms of concept and application. In addition, the study showed that more than half of the study sample has a long job experience (11-15 years).

General information about the studied companies: The results of the current study showed that $77.6 \%$ of the studied companies have an independent social responsibility department which indicates that companies in Saudi Arabia have become more aware of social responsibility and the shift in the concept of social responsibility from being charitable and voluntary to make it essential in companies through an independent specialized department have its own policies and strategies which makes it able to estimate and understand the community needs. In addition, many companies are moving employees to CSR departments as a retention strategy. As well, the results of this study showed that most of the studied companies (93.6\%) are of IPO (Initial Public Offering) where the process of offering is important in the involvement of citizens and the private sector in these companies which increases the productivity.

As that the Public Offering (PO) is one of the tools that meet the needs of the company for financial resources and one of the means of distributing investment risks to a larger slice of investors indicates that these companies have an effective internal administrative and financial organization and have strong internal control methods that qualify them to carry out social responsibility activities appropriately. On the other hand, most of these companies $(92.3 \%$ ) have capital exceeding one million Saudi Riyals (92.3\%) and $44.9 \%$ have more than 10,000 workers. This is evidence that it is large-sized companies. Herein, company size factor as an affective factor on its performance and commitment to social responsibility where some studies including Adeneya and Ahmed (2015) on corporate social responsibility and the performance of the company stated that there is no statistically significant relationship between CSR and company size.

The results of this study showed that the highest percentage of these companies $(60.9 \%)$ has been listed for a not short period of time in the Saudi Stock Market which exceeding 12 years while for $25.2 \%$ of the companies its listing in the Saudi Stock Market does not exceed 7 years, indicating that these companies have experienced a high rate of investment success in the long term.

With regard to the number of branches of the studied companies, the results of the current study showed that some of these companies have more than 50 branches but the majority $(65.4 \%)$ has one to ten branches. This is a expected result due to the large size of these companies in terms of the number of workers and the size of their capital. As mentioned before that most of these companies has a capital of more than 1 million riyals.

Corporate financial performance: Previous researches inconsistently has used one or a few measures to assess financial performance, this such a way appears to be based on the researcher's comfort in terms of ease of data acquisition for analysis. Friedman $(1962,1970)$ used net income and Vance (1975) used earnings per share. Abbott and Monsen (1979) used the return on investors and Bowman and Haire (1975) used the return on equity. Most researchers have recently used growth indicators such as return on equity for 5 years Cochran and Wood (1984) or the use of assets such as return on assets (Wokutcho and McKinney, 1991). Some studies in the Arab environment have used two different indicators 
Table 2: Corporate financial performance (SR million)

\begin{tabular}{llcc}
\hline Years & $\begin{array}{c}\text { Average net } \\
\text { income }\end{array}$ & $\begin{array}{c}\text { Average retum } \\
\text { on assets }\end{array}$ & $\begin{array}{c}\text { Average return } \\
\text { on equity }\end{array}$ \\
\hline 2015 & 85.623 .071 .27 & 2.264 .43 & 9.88 \\
2014 & 109.031 .340 .36 & 55.64 & 47.58 \\
2013 & 82.305 .343 .93 & 8.01 & 10.70 \\
2012 & 71.393 .124 .92 & 7.74 & 10.64 \\
2011 & 3.301 .205 .38 & 15.51 & 3.16 \\
\hline
\end{tabular}

to measure financial performance such as the study of Omar which used the return on assets which measures the company's efficiency in using its assets during the fiscal year and return on equity which measures the companys efficiency in using equity during the financial year. They are measured by dividing net profit after tax on total shareholder's equity. With regard to the financial performance of companies in our current study, the financial performance assessment was based on average net income, average return on assets and average return on equity for the years (2011-2015), the highest average net income was SR 109, 031, 340.36 in the year (2014) and the lowest was in the year (2011) with average net income of (SR 3, 301, 205.38). As for the return on the average assets, the highest average was in the year (2015) SR 2, 264.43 millions and the lowest was in the year (2012) (SR7.74 million). As regards to the return on average equity it was 47.58 million Saudi Riyals in the year (2014) (Table 2).

The measurement CSR activities for the companies listed at the Saudi Stock Exchange: In order to assess to what extent CSR are applied by the companies that listed on the Saudi Stock Exchange, this study measured the social responsibility activities by evaluating the different aspects of these activities. Despite the different classifications facing the process of determining activities related to social responsibility, the current study examined six basic social activities through which companies can practice their social responsibilities: community service activities, environmental resource development activities, employe's related activities, client's related activities in addition to the corporate social responsibility towards corporate governance and organizational performance.

Corporate social responsibility towards society: The results of social responsibility of the company towards community showed that the study sample were absolutely agreed that the companies are doing their responsibility towards society (agreement average $=4.30$ out of 5 ) and they believe that owning clear and ethical guide declared for all employees it was the most important act these companies do to their social responsibility towards society.
Corporate social responsibility towards the environment: In regards to CSR towards environment, the sample was also absolutely agreed that the companies are responsible for the environment with an average of 4.24 out of 5 . They believe that the participation of the companies in the development of environmental protection programs by private associations and agencies it was the most important act these companies do to their social responsibility towards the environment but they were not satisfied with readiness of company for discussion and exchange views with those responsible and interested for the environment, this lack of readiness for discussion can be attributed to not having independent department designated for tasks and duties of social responsibility.

Corporate social responsibility towards employees: Oncerning CSR towards employees, the sample was also absolutely agreed that the companies are doing their responsibility towards employees (agreement average $=4.70$ out of 5) and they confirm that all employees of the company are subject to the health insurance program while they were less agree with regard to the involvement of employees in the decision-making process of the company.

Corporate social responsibility towards customers: The target of responsibility is the stakeholders which includes the customers or the buying public. The perception of offering respect and satisfaction to customers is nothing new to businesses but being responsible to customers creates an impact on profitability. In this context, there was a full agreement that the companies are doing their responsibility towards customers with an average of (4.76 out of 5). This result concludes that the employees of the companies were totally agreed that companies were fully responsible to the customers which represented by the company's listening to the views and suggestions of the customers where it responds to the complaints submitted by them and working to solve them in addition to dealing with transparency and integrity with their customers and maintain the security and safety of customers and their money and all related data and information.

Corporate social responsibility and governance principles: Regarding social responsibility of the company and the principles of governance our study revealed that printing specialized publications enhance the company's practice in the field of accounting and 


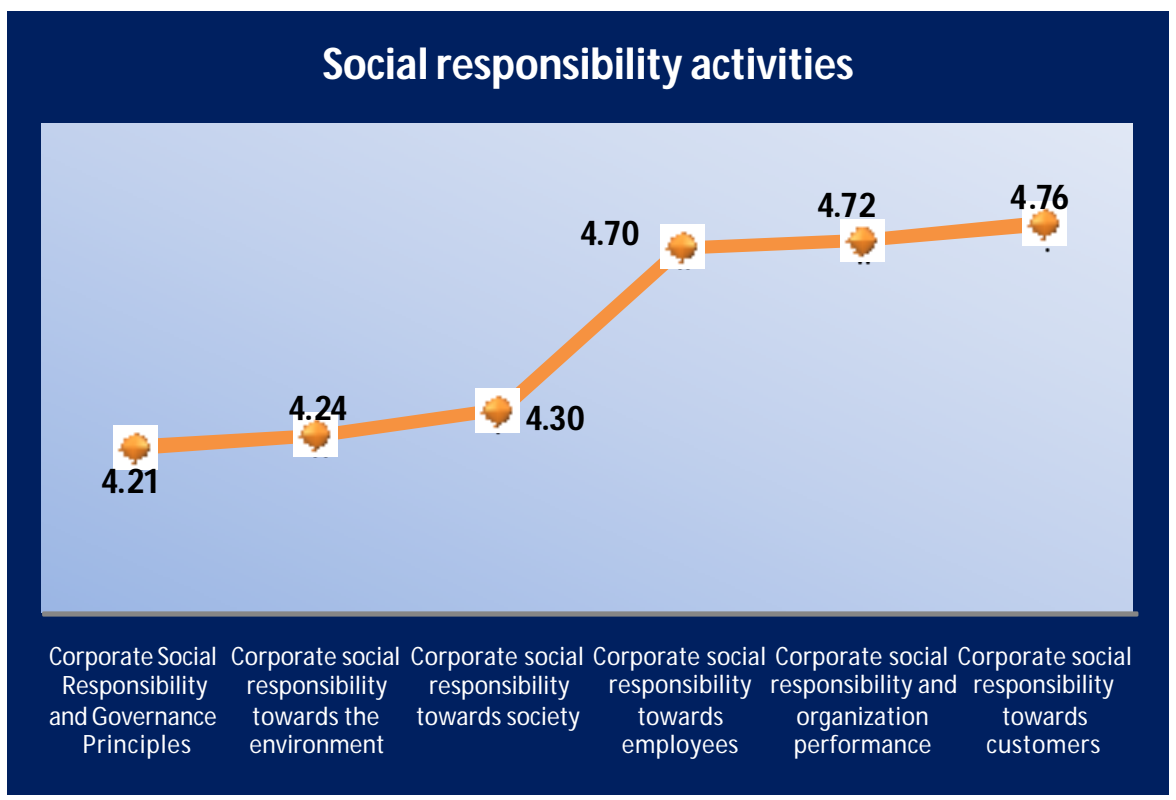

Fig. 1: Social responsibility activities

disclosure of social responsibility was at the forefront of what companies are doing about the social responsibility and the principles of governance this item had got a full agreement by the study sample with an average ( 4.34 out of 5). Corporate compliance with corporate governance principles was represented by the printing of specialized bulletins which improve the company's practice in the area of accounting and disclosure of social responsibility but at the same time there are no accounting standards for measuring and presenting the social impacts of these activities it also avoids the disclosure of social and environmental information that could cause a decline in revenue and future cash flows as it considers that the expected financial returns from its disclosure of social responsibility are $>$ the costs of disclosure and that disclosure of social responsibility may affect to some extent the ability of the company to obtain funding.

Corporate social responsibility and organization performance: The results of CSR and the performance of the organization showed that the sample of our study were fully agreed (average score $=4,62$ of 5) that social responsibility helps companies to improve their image and strengthen their reputation in the community. They were also absolutely agreed that companies believe that engaging in social responsibility practices is increasing their long-term profits. In addition, companies are using CSR as a source of competitive advantage (Fig. 1).

Figure 1 illustrate that Corporate Social Responsibility (CSR) towards customers was the main CSR activity for companies listed on the stock market due to the heist mean (4.76 of 5) followed by corporate social responsibility and organization performance then corporate social responsibility towards employees. This result was consistent with study of that attention to the customers of the bank came first while the areas of employees, community and environment were ranked second, third and fourth, respectively. However, in some studies the opposite is true. In the study of which an evaluation study of a group of banks operating in Algeria, about social and environmental responsibility in the banking sector we find that social responsibility towards customers came at the end of the list while social responsibility activities towards employees ranked first in terms of social responsibility activities towards society.

\section{Testing hypothesis}

Testing the main hypothesis: Saudi companies do not play their role in social responsibility.

Null Hypothesis $\mathbf{H}_{0}$ : Saudi companies do not play their role in social responsibility.

Alternative Hypothesis $\mathbf{H}_{\mathbf{l}}$ : Saudi companies play their role in social responsibility. To testing this hypothesis, the aggregate mean and standard deviation of the six CSR scales were separately produced in addition to the combined mean of these scales. It was found that the application of social responsibility standards by Saudi companies was very high (4.49 out of 5). However, there were varying degrees of application. The overall averages of these standards ranged between (4.21 and 4.76). The application of CSR towards customers came at the top in 
- Coporate social responsibility towards customers

a Coporate social responsibility and organization performance

Coporate social responsibility towards employees

Coporate social responsibility towards society

Coporate social responsibility towards the environment

Coporate social responsibility and governance principles

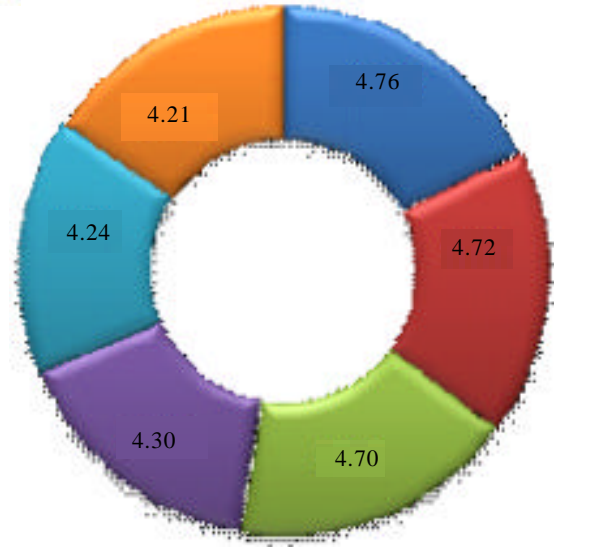

Fig. 2: The extent to which companies apply social responsibility standards. The total score of application os social resposibility standard = $4.45 \pm 0.36$

terms of applying (mean $=4.76$ ), the lowest of which is the corporate social responsibility and the principles of governance $($ mean $=4.21)$. The overall average of these dimensions was (4.49 of 5) indicates that the Saudi companie's application of social responsibility standards was high. Based on these results, Saudi companies play their role in social responsibility. Therefore, the null hypothesis was rejected (Fig. 2).

Testing the second hypothesis: There are statistically significant differences at the level of $(0.05)$ in the degree of application of Saudi social responsibility measures according to some selected independent variables such as (sector, availability of an independent department of social responsibility in companies, listing years of the company in the Saudi Stock Market).

Null Hypothesis $\mathbf{H}_{\mathbf{0}}$ : There were no statistically significant differences at the level of (0.05) in the degree of application of Saudi social responsibility measures according to some selected independent variables such as (sector, availability of an independent department of social responsibility in companies, listing years of the company in the Saudi Stock Market).

Alternative Hypothesis $\mathbf{H}_{\mathbf{l}}$ : There were statistically significant differences at the level of $(0.05)$ in the degree of application of Saudi social responsibility measures
Table 3: One-way ANOVA results for the differences in Saudi companie's application of social responsibility according to sector

\begin{tabular}{|c|c|c|c|c|c|}
\hline CSR scales & $\begin{array}{l}\text { Sum of } \\
\text { squares }\end{array}$ & $\mathrm{df}$ & $\begin{array}{l}\text { Mean } \\
\text { square }\end{array}$ & F-values & Sig. \\
\hline \multicolumn{6}{|c|}{ CSR towards society } \\
\hline Between groups & 1.359 & 14 & 0.097 & 0.650 & 0.819 \\
\hline Within groups & 21.070 & 141 & 0.149 & & \\
\hline \multicolumn{6}{|l|}{$\begin{array}{l}\text { CSR towards } \\
\text { environment }\end{array}$} \\
\hline Between groups & 4.004 & 14 & 0.286 & 0.511 & 0.923 \\
\hline Within groups & 78.847 & 141 & 0.559 & & \\
\hline \multicolumn{6}{|l|}{$\begin{array}{l}\text { CSR towards } \\
\text { employees }\end{array}$} \\
\hline Between groups & 9.964 & 14 & 0.712 & 8.566 & $0.000^{t+k}$ \\
\hline Within groups & 11.714 & 141 & 0.083 & & \\
\hline \multicolumn{6}{|l|}{$\begin{array}{l}\text { CSR towards } \\
\text { customers }\end{array}$} \\
\hline Between groups & 8.264 & 14 & 0.590 & 6.368 & $0.000^{* 1+k}$ \\
\hline Within groups & 13.070 & 141 & 0.093 & & \\
\hline \multicolumn{6}{|c|}{$\begin{array}{l}\text { Csr and governance } \\
\text { principles }\end{array}$} \\
\hline Between groups & 5.859 & 14 & 0.418 & 0.836 & 0.629 \\
\hline Within groups & 70.574 & 141 & 0.501 & & \\
\hline \multicolumn{6}{|c|}{$\begin{array}{l}\text { CSR and organization } \\
\text { performance }\end{array}$} \\
\hline Between groups & 5.834 & 14 & 0.417 & 2.204 & $0.010^{*}$ \\
\hline Within groups & 26.667 & 141 & 0.189 & & \\
\hline
\end{tabular}

*Significant at the 0.05 level; **:Significant at the 0.01 level

according to some selected independent variables such as (sector, availability of an independent department of social responsibility in companies, listing years of the company in the Saudi Stock Market)

\section{Firstly}

Differences in the extent to which Saudi companies apply CSR Standards according to sector: The difference between companies in their performance of social responsibility).

The hypothesis reads as follows: "There are statistically significant differences in the extent to which Saudi companies apply CSR Standards according to sector". To testing this hypothesis, one-way ANOVA was used (Table 3).

As shown in the above table there were no significant differences $(p>0.05)$ in the extent to which Saudi Companies applied CSR in regard to CSR towards society, environment and governance principles while ANOVA revealed statistically significant differences at (0.05) according to the sector in terms of CSR towards employees, customers and CSR and organization performance $(p<0.01,0.05)$. To determine the source of differences, Post-Hoc. Multiple comparisons using scheffe test was conducted, except for CSR dimension (Corporate Social Responsibility towards the customers). LSD test have been used because Scheffe test was not able to find out the source of differences for this dimension. Significant differences at level 0.01 were 


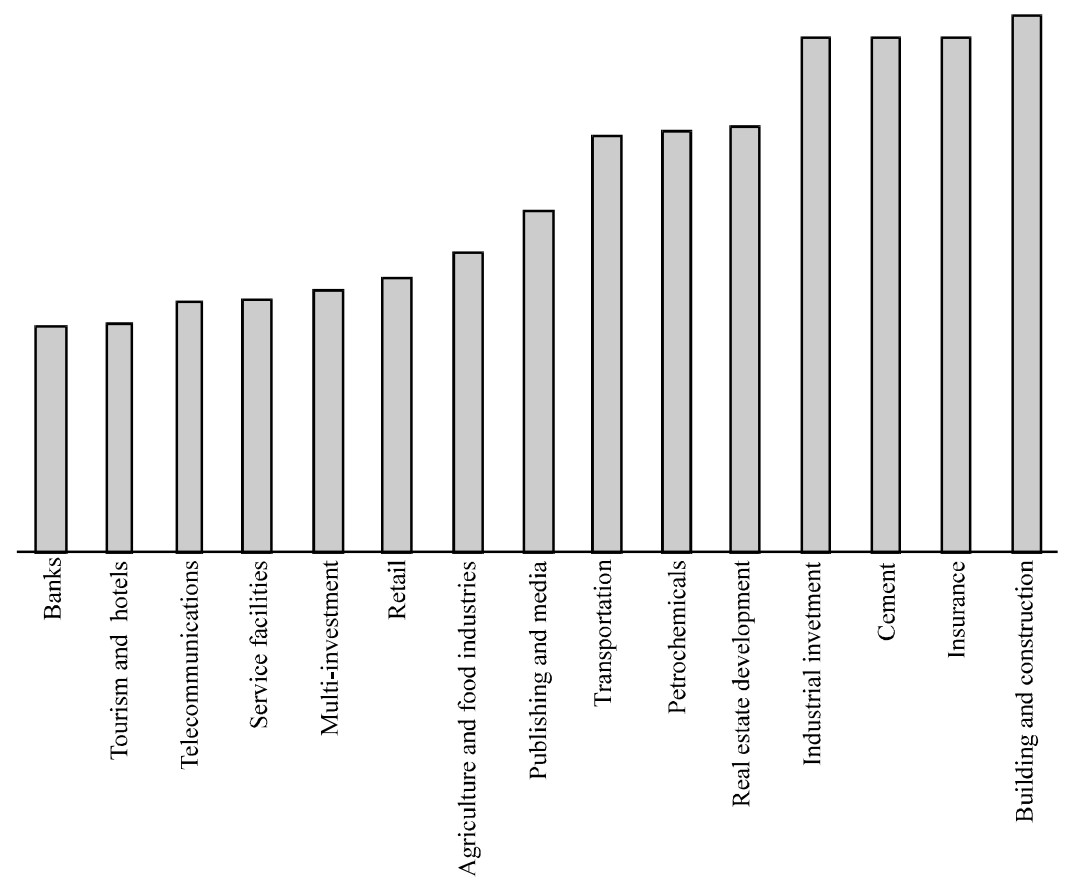

Fig. 3: Application level of corporate social responsibility towards employees

occurring in the application of CSR towards employees according to the sector between insurance sector and (banks, retail, agriculture and food industries) on the other hand. The differences were in favor of (insurance sector) due to the highest mean (4.95).

As well, there were significant differences at level 0.05 in the application of CSR towards employees according to the sector between the banking sector and sectors of (construction-cement-industrial investment) on the other hand. The differences trends were in favor of these sectors (means $=4.99,4.94$ and 4.94), respectively.

There are also statistically significant differences at level 0.01 in the application of CSR towards employees according to the sector between the retail sector and the sectors of (construction-cement-industrial investment). The differences trends were in favor of these sectors (means $=4.99,4.94$ and 4.94), respectively (Fig. 3).

Significant difference at level 0.01 was occurring in the application of CSR towards customers according to the sector between insurance sector and (banks). The difference was in favor of (insurance sector) due to the highest mean (4.97).

There were also significant differences at level 0.05 between banking sector and the sectors of (cement and industrial investment). The differences trends were in favor of these sectors (means $=4.98,4.95$ ), respectively (Fig. 4). There were significant differences at level 0.05 in the application of CSR and organization performance according to the sector. The differences were between insurance sector and the sectors of (banking-telecommunication-retail-agriculture and food industry). The differences trends were in favor of insurance sector due to the highest mean (means $=4.88)$.

As well, there were significant differences at level 0.05 in the application of CSR and organization performance according to the sector. The differences were between services facilities sector and the sector of telecommunication. The difference trend was in fav or of service facilities due to the highest mean (means $=5.00$ ). As well, there were significant differences at level 0.05 , 0.01 in the application of CSR and organization performance according to the sector. The differences were between construction sector and the sector of (banking, telecommunication, petrochemicals, retail, agriculture and food industry). The difference trend was in favor of construction sector due to the highest mean (means $=5.00$ ).

Also, there were significant differences at levels $0.05,0.01$ in the application of CSR and organization performance according to the sector. The differences were between cement sector and the sectors of (banking, telecommunication, retail and agriculture and food industry). The difference trend was in favor of cement sector due to the highest mean (means $=4.89$ ). Also, there were significant differences at levels 0.05 in the 


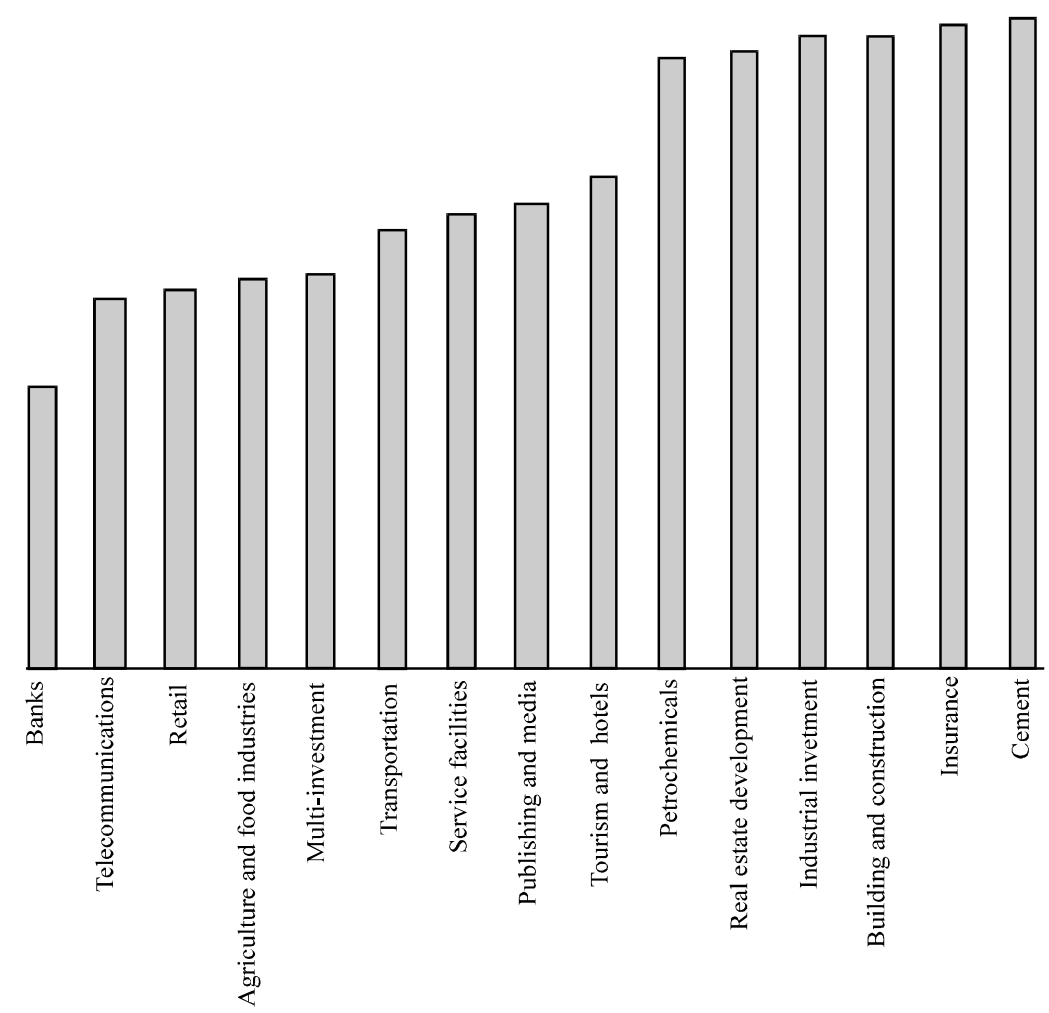

Fig. 4: Application level of corporate social responsibility towards customers

application of CSR and organization performance according to the sector. The differences were between industrial investment sector and the sectors of (banking, telecommunication, retail and agriculture and food industry). The difference trend was in favor of industrial investment sector due to the highest mean (means $=4.90$ ). Based on the above results, the null hypothesis will be rejected in regards to (CSR towards employees, customers and CSR and organization performance) and accepted for CSR towards the community, environment and governance principles (Fig. 5).

\section{Secondly}

Differences on the application of CSR according to availability of an independent department for CSR in the companies

Null Hypothesis $\mathbf{H}_{0}$ : "There are no statistically significant differences in the application of CSR activities by Saudi companies according to availability of a designated independent department for CSR in the companies".

Alternative Hypothesis $\mathbf{H}_{1}$ : "There are statistically significant differences in the application of CSR activities by Saudi companies according to availability of a designated independent department for CSR in the companies".

To testing this hypothesis, independent samples $\mathrm{t}$ test was used. As shown in table no statistically significant differences were found regarding application of CSR according to a designated independent department for social responsibility in the company $(p>0.05)$. This result indicates that the existence of a separate section for social responsibility in the companies does not affect the extent of their application of social responsibility activities.

Since, the results of $t$ test were insignificant ( $p>0.05$ ). So, the null hypothesis was accepted. Therefore we can conclude that are no statistically significant differences in the application of CSR activities according to availability of a designated independent department for CSR in the companies. Or by other word this designated independent department for CSR have no effect on the company's commitment to implementation of CSR activities.

\section{Thirdly}

Differences in the application of CSR activities in regards to listing period in the Saudi Stock Market

To test this hypothesis: "There are statistically significant 


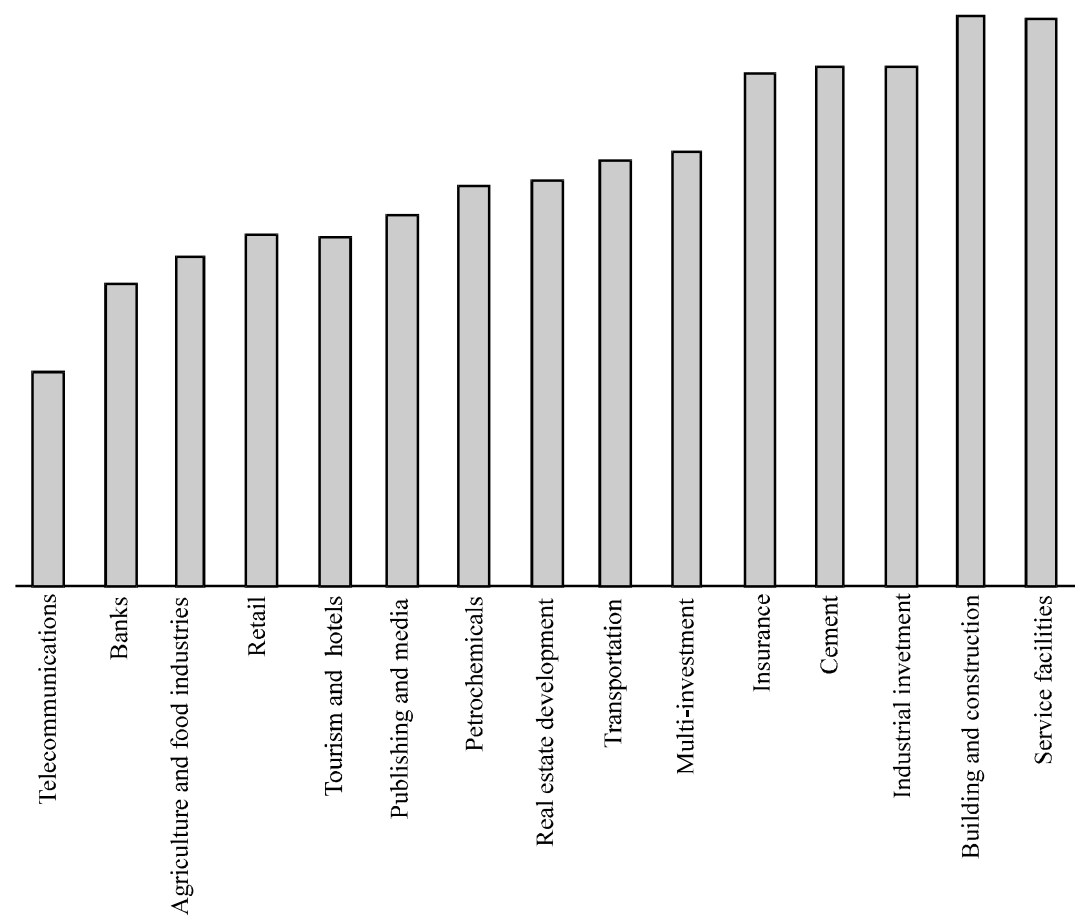

Fig. 5: Application level of corporate social responsibility and organization performance

differences in the application of CSR activities according to listing period in the Saudi Stock Market", we examined the differences between company's CSR applications according to listing period in the Saudi Stock Market. The results as follows.

No statistically significant differences showed by ANOVA. This finding indicates that the duration of listing in the Saudi Stock Market has no role in the application of social responsibility activities by Saudi Companies. Since, the ANOVA was statistically insignificant $(p>0.05)$. Therefore, the null hypothesis was accepted.

However, when comparing the application of social responsibility activities for companies listed on the stock market before 1-3 years ago with those listed 12 years ago and more, significant differences were found only in the application of CSR towards the employees among companies listed on the stock market 1-3 years ago and those listed 12 years ago $(t=1.898, \mathrm{p}<0.05)$. the difference was in favor of recent listing companies (mean $=4.84$ ) in contrast to (mean $=4.66$ ) for companies listed 12 years ago, respectively. Therefore, $\mathrm{H}_{1}$ is supported (Anonymous, 1997).

This result suggests that companies are newly listed on the stock market are more applicable to social responsibility towards employees than those that have been listed for a long time (Table 4 and 5).

Application of CSR activities by Saudi companies according to capital: As for the differences in the
Table 4: Independent samples t test results for the differences in Saudi companie's application of social responsibility according to listing years in the stock market (1-3 and 12) y ears and more

CSR dimensions/Listing years

\begin{tabular}{lccccc} 
in the stock market & No. & Mean & SD & t-values & Sig. \\
\hline CSR towards society & & & & & \\
$1-3$ & 15 & 4.31 & 0.27 & 0.379 & 0.706 \\
12 and more & 56 & 4.28 & 0.31 & & \\
CSR towards environment & & & & & \\
$1-3$ & 15 & 4.37 & 0.41 & 0.794 & 0.430 \\
$\begin{array}{l}12 \text { and more } \\
\text { CSR towards employees }\end{array}$ & 56 & 4.22 & 0.70 & & \\
$1-3$ & 15 & 4.84 & 0.27 & 1.898 & $0.032^{*}$ \\
12 and more & 56 & 4.66 & 0.36 & & \\
CSR towards customers & & & & & \\
$1-3$ & 15 & 4.88 & 0.27 & 1.606 & 0.113 \\
$\begin{array}{l}12 \text { and more } \\
\text { CSR and governance principles }\end{array}$ & 56 & 4.70 & 0.40 & & \\
$\begin{array}{l}1-3 \\
12 \text { and more }\end{array}$ & 15 & 4.26 & 0.56 & 0.139 & 0.890 \\
CSR and organization & 56 & 4.23 & 0.64 & & \\
per formance & & & & & \\
$\begin{array}{l}1-3 \\
12 \text { and more }\end{array}$ & 15 & 4.85 & 0.26 & 0.796 & 0.428 \\
\hline
\end{tabular}

* Significant at the 0.05 level 1

Table 5: Distribution of companies by capital

\begin{tabular}{lll}
\hline Capital (SR million) & No. & Percentage \\
\hline $10-50$ & - & - \\
$51-100$ & 5 & 3.2 \\
More than 100 & 144 & 92.3 \\
Missing & 7 & 4.5 \\
Total & 156 & 100.0 \\
\hline
\end{tabular}

application of CSR according to companies capita it is not possible to conduct a statistical test, since, the majority of 
Table 6: CSR composite index according to sectors

\begin{tabular}{lcc}
\hline Sectors & CSR index & Rank \\
\hline Banks & 0.641 & 1 \\
Tourism and hotels & 0.578 & 2 \\
Building and construction & 0.452 & 3 \\
Telecommunications & 0.386 & 4 \\
Retail & 0.361 & 5 \\
Multi-investment & 0.354 & 6 \\
Insurance & 0.342 & 7 \\
Cement & 0.317 & 8 \\
Industrial investment & 0.297 & 9 \\
Agriculture and food industries & 0.289 & 10 \\
Publishing and media & 0.18 & 11 \\
Service facilities & 0.073 & 12 \\
Petrochemicals & 0.030 & 13 \\
Real estate development & 0.029 & 14 \\
Transportation & 0.001 & 15 \\
\hline
\end{tabular}

the companies 144 (in this study) had a capital of more than 100 million riyals $(92.3 \%)$ only 5 companies have a capital ranged 51-100 million riyals, the difference between them is very large in terms of number, so that, the statistical test in this case does not give reliable results (Table 6).

Testing third hypothesis; Ompany size has no statistically significance impact on its social performance

Null Hypothesis $\mathbf{H}_{\mathbf{0}}$ : Company size has no statistically significance impact on its social performance.

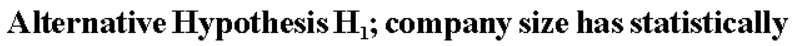
significance impact on its social performance: To test this hypothesis by assuming that company's capital, average net income and average return on assets representing the size and performance of the company. Multiple Regression Analysis (MRA) was utilized to find out the impact of (size and performance of the company) on CSR (the dependent variable). Regression equation has $0.03 \% \mathrm{R}^{2}$ and $\mathrm{F}$-statistic is not significant at 0.05 level. The $\mathrm{R}^{2}$ implies that the $0.03 \%$ of the variation in CSR disclosure is explained by company size. It's clear that all those variables (company's capital, average net income and average return on assets) can interpret only $0.03 \%$ of the change in the social responsibility, Since, ANOVA test was not significant ( $p>0.05$ ). So, we accept the null hypothesis and reject the alternative because the regression is not significant and therefore, there is no relationship between independent variables and dependent variable (social responsibility).

The Spearman's rho correlation coefficient was then used to determine the relationship between the company capital and the dependent variable CSR. As well, person correlation coefficient was used to determine the relationship between (average net income, average return on assets and average return on equity) and the dependent variable (CSR). All Spearman and Pearson correlation coefficients were found to be insignificant ( $p>0.05$ ). Therefore, the answer to the second research question is that the size of the company and its performance does not affect its role in social responsibility but it can be attributed to other factors that affect the companies in turn towards social responsibility. This finding is consistent with the Yusuf study about the impact of corporate social responsibility on the performance of the company which showed that there is no statistically significant relationship between CSR and size while there was a positive relationship between CSR and the market to book value and return on capital.

\section{Building of Saudi corporate social responsibility index:} The CSR index was constructed by applying the basic steps for the formation of composite indicators. The sub-indicators were identified according to the theoretical framework as follows:

- Corporate social responsibility towards community

- Corporate social responsibility towards the environment

- Corporate social responsibility towards employees

- Corporate social responsibility towards customers

All steps of indexing were done using the SPSS program and the reliability analysis was conducted to examine the consistency between these sub-indicators and the appropriateness of using these sub-indices together to form a single composite index. Reliability was analyzed by the Cronbach's alpha coefficient and gave a good estimate of reliability $(0.767)$. Internal correlation matrix was also produced. The factor analysis was then used by using the principle components method, the coefficients matrix of the factors were dealt with after rotation and these factors were then aggregated to form the composite index.

\section{CONCLUSION}

In the light of the results of the current study, the researcher reached the following results. The practice of Saudi companies listed in the stock market for social responsibility activities reflected a high degree and the most highest is the practice regarding the social responsibility towards customers. There is slight decline in the practice regarding social responsibility and principals of governance. The study showed that the Saudi companies play their role towards social responsibility as they fulfill all activities of social responsibility. 
The study showed variation between companies in performing the social responsibility. The study showed that the existence of an independent department for social responsibilities at the companies not affect the implementation of social responsibility activities. The study showed that the duration of listing the companies in the stock market has no effect on the implementation of the social responsibility activities in general.

The study showed differences of statistical significance on the dimension of (social responsibility of the company towards the employee) between the companies listed in the stock market for a short time and those listed for a long time (more than 12 years). The current study results showed that there is no statistical significance relation between the company size and social responsibility.

\section{RECOMMENDATIONS}

It is necessary to find a complementary plan combining all efforts to identify the required targets and the roles to be played by companies and the indicators that allow to measure the impact of the companies for evaluation of its contribution and follow up, preferably to be the general authority for investment in order to re-establish the priorities and principles to be dealt with.

The authority must establish an indicator for social responsibility according to the international successful experiences in order to measure the success of the social responsibility programs. The companies must be evaluated in the stock market according to this indicator. Further cooperation with capital market authority as a basic monitor for the listed companies.

Encouraging companies for disclosure and transparency and to adopt certain standards about the financial data regarding social responsibility programs and the amounts allocated and in case of none fulfilling. Arranging the priorities of social development which must be considered by business sector. There must be administrative structure for social responsibility for the companies in order to present periodical reports about the programs of social responsibility. Identifying a time frame for implementation of this strategy and to choose some indicators to measure the success of strategic programs in achieving the required goals.
Involvement of the civil society in the programs of social responsibility through organization of educational courses and programs about social responsibilities, beside providing consultation services, conducting of conferences to improve communications also supporting the implementation of social responsibility programs, establishing information centers to propagate social awareness along with presenting publications and studies about the social responsibilities.

\section{REFERENCES}

Abbott, W.F. and R.J. Monsen, 1979. On the measurement of corporate social responsibility: Self-reported disclosures as a method of measuring corporate social involvement. Acad. Manage. J., 22: 501-515.

Adeneye, Y.B. and M. Ahmed, 2015. Corporate social responsibility and company performance. J. Bus. Stud. Q., 7: 151-166.

Allen, M.J. and W.M. Yen, 2002. Introduction to Measurement Theory. Waveland Press, Illinois, USA., ISBN:9781577662303, Pages: 310.

Anonymous, 1997. National development plan 1997-2001. Government Press, Nairobi, Kenya.

Bowman, E.H. and M. Haire, 1975. A strategic posture toward corporate social responsibility. California Manage. Rev., 18: 49-58.

Cochran, P.L. and R.A. Wood, 1984. Corporate social responsibility and financial performance. Acad. Manage. J., 27: 42-56.

DeGeorge, R.T., 1995. Business Ethics. 4th Edn., Prentice-Hall, Englewood Cliffs, New York, USA.,

Friedman, M., 1962. Capitalism and Freedom. University of Chicago Press, Chicago, pp: 133

Friedman, M., 1970. The social responsibility of business is to increase its profits. N. Y. Times Mag., 13: 32-33.

Moura-Leite, R.C. and R.C. Padgett, 2011. Historical background of corporate social responsibility. Soc. Responsibility J., 7: 528-539.

Sekaran, U., 2003. Research Methods for Business: A Skill Building Approaches. 4th Edn., John Wiley and Sons Inc., New York.

Vance, S., 1975. Are socially responsible firms good investment risks? Manage. Rev., 64: 18-24.

Wokutch, R.E. and E.W. McKinney, 1991. Behavioral and perceptual measures of corporate social performance. Res. Corporate Social Perform. Policy, 12: $309-330$. 